\title{
ХАРАКТЕРИСТИКА МЕСТОРОЖДЕНИЙ НЕФТИ, ГАЗА И КОНДЕНСАТА В ИРКУТСКОЙ ОБЛАСТИ
}

\author{
А. В. Новиков, Е. Ю. Богомолова, И. С. Кородюк \\ Байкальский государственный университет, г. Иркутск, Российская Федерация
}

Информация о статье

Дата поступления

14 июля 2017 г.

Дата принятия к печати 20 ноября 2017 г.

Дата онлайн-размещения 27 ноября 2017 г.

\section{Ключевые слова}

Нефть; газ; газовый конденсат; месторождения; запасы; ресурсы; недропользователи; нефтегазовый комплекс; Иркутская область

\begin{abstract}
Аннотация
Иркутская область является одним из крупнейших регионов Российской Федерации по запасам углеводородного сырья. В статье представлена характеристика месторождений нефти, газа и конденсата в Иркутской области по их типам (нефтяное, нефтегазовое, газовое, газоконденсатное, нефтегазоконденсатное) и году открытия. Проведено исследование объемов извлекаемых ресурсов и запасов нефти и газа по их категориям, по недропользователям и другим характеристикам. Приведена динамика объемов добычи нефти, газа и конденсата в Иркутской области. Проанализирована динамика числа выдаваемых Роснедрами и Иркутскнедрами лицензий на пользование углеводородным сырьем на территории Иркутской области. Проведено сравнение объемов геологоразведочных работ по важнейшим видам полезных ископаемых, а также представлена динамика объемов глубокого разведочного бурения на нефть и газ в Иркутской области. Объемы геологоразведочных работ ежегодно увеличиваются, в связи с чем имеются хорошие предпосылки для открытия новых месторождений нефти, газа и конденсата.
\end{abstract}

\section{CHARACTERISTICS OF OIL, GAS AND GAS CONDENSATE FIELDS OF IRKUTSK OBLAST}

\author{
Alexander V. Novikov, Evgeniya Yu. Bogomolova, Igor S. Korodyuk \\ Baikal State University, Irkutsk, Russian Federation
}

Article info

Received

July 14, 2017

Accepted

November 20, 2017

Available online

November 27, 2017

\section{Keywords}

Oil; gas; gas condensate;

deposits; reserves; resources; well users; oil and gas industry; Irkutsk Oblast

\begin{abstract}
Irkutsk Oblast is one of the largest regions of the Russian Federation in terms of hydrocarbon reserves. The article presents the characteristics of oil, gas and condensate fields of Irkutsk Oblast according to their type (petroleum, oil and gas, gas, gas condensate, oil and gas condensate) and the year of discovery. The authors studied the volume of the recoverable resources and reserves of oil and gas according to their categories, well users and other characteristics. They show the dynamics of production of oil, gas and condensate in Irkutsk Oblast and analyse the dynamics of the number of the licences to use subsoil hydrocarbon resources on the territory of Irkutsk Oblast issued by the Rosnedra and Irkutsknedra. The authors also compare the volume of geological exploration for the most important types of minerals, and show the dynamics of deep exploratory drilling for oil and gas in Irkutsk Oblast. The volume of geological exploration increases every year, which creates the good prerequisites for discovery of new deposits of oil, gas and condensate.
\end{abstract}

В настоящее время Иркутская область является одним из крупнейших регионов Российской Федерации по запасам углеводородного сырья, такого как нефть, газ и конденсат [1-3]. В Иркутской области расположено более трех десятков месторождений нефти, газа и конденсата, наиболее крупные из которых Ковыктинское газоконденсатное [4] и Верхнечонское нефтегазоконденсатное месторождения'. В середине XX в.

1 Объемы запасов ПАО «Верхнечонскнефртегаз» [Электронный ресурc]. URL: https://vcng.rosneft. ru/about/Glance/OperationalStructure /Dobicha_i_ razrabotka/Vostochnaja_Sibir/vcng/Obemi_zapasov. 
ситуация по разведанным запасам нефти и газа была совершенно иная: в 1947 г. на специальной конференции, посвященной развитию производительных сил Восточной Сибири, авторитетнейший геолог иркутянин Сергей Владимирович Обручев утверждал, что в регионе никогда не удастся обнаружить сколько-нибудь значительных запасов нефти и газа, так как местные геологические структуры не способствуют образованию месторождений промышленного значения. Однако 18 марта 1962 г. трестом «Востсибнефтегеология» на территории Иркутской области было открыто первое месторождение - Марковское [5, с. 17].

В статье М. А. Винокурова «Ресурсы и запасы природного газа в Иркутской области» дано описание 14 месторождений, которые были открыты до 2009 г. [6]. На рис. 1 представлена динамика количества открытых месторождений нефти, газа и конденсата в Иркутской области по десятилетним интервалам.

Если в 1960-е гг. было открыто всего одно месторождение, то в 1970-е - уже восемь [7]. В очень тяжелый для страны период девяностых не было открыто ни одного нового месторождения, зато в последнее время наблюдается бум открытий: за семь лет открыто уже 17 месторождений. О дате открытия трех месторождений у нас информации нет.

В 2016 г. на Верхнеичерском участке открыто новое месторождение - Верхнеичерское нефтегазоконденсатное (ПАО «НК «Роснесть»).

На территории Иркутской области по состоянию на 1 января 2017 г. в общей сложности открыто 38 месторождений нефти, газа и конденсата (рис. 2).

По фразовому составу третья часть месторождений Иркутской области относится к однокомпонентным (газовые или нефтяные), остальные две трети - многокомпонентные (газоконденсатные, нефтегазовые или нефтегазоконденсатные).

По состоянию на 1 января 2016 г. в распределенном фонде находится 73 участка недр ${ }^{2}$. Сведения о компаниях-недропользователях, объектах недропользования и номерах лицензий приведены в табл. 1.

${ }^{2} \mathrm{O}$ состоянии и об охране окружающей среды Иркутской области в 2016 году : гос. докл. / ООО «Мегапринт». Иркутск, 2017. С. 28-30.

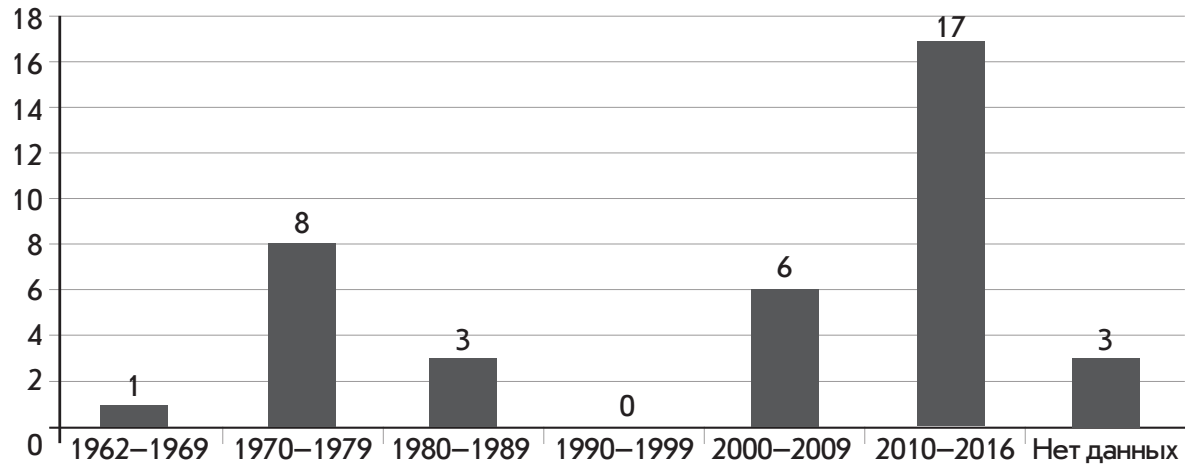

Рис. 1. Динамика количества открытых месторождений нефти, газа и конденсата в Иркутской области, ед.

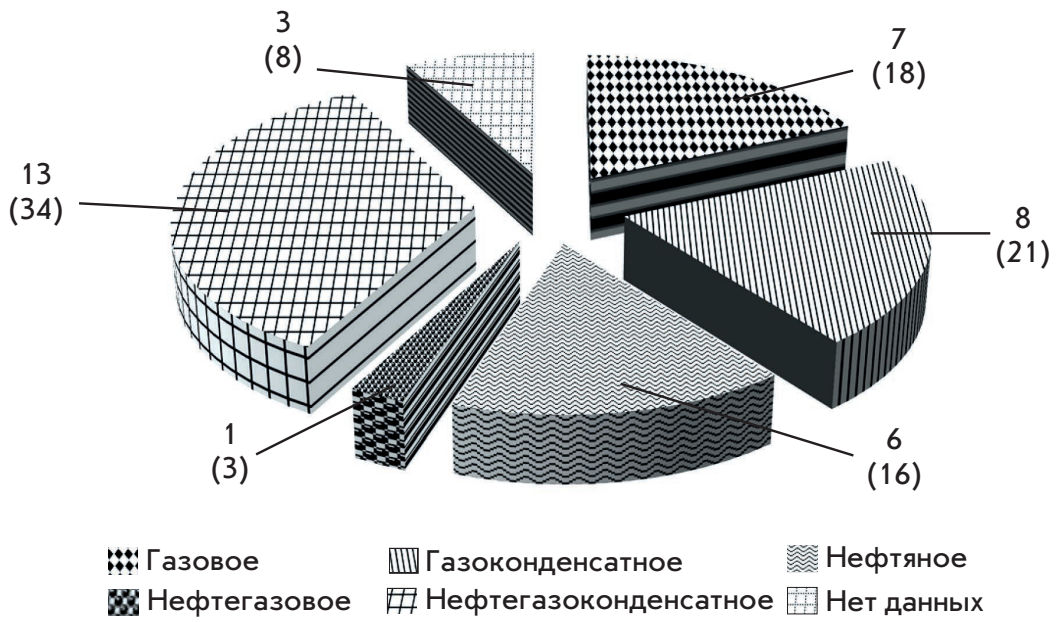

Рис. 2. Структура месторождений нефти, газа и конденсата Иркутской области по типу, ед. (\%) 
аблица 1

Участки распределенного фонда недр Иркутской области (по состоянию на 1 января 2016 г.)

\begin{tabular}{|c|c|c|c|}
\hline Недропользователь & $\begin{array}{l}\text { № } \\
\Pi / \Pi\end{array}$ & $\begin{array}{c}\text { Наименование участка } \\
\text { или месторождения }\end{array}$ & $\begin{array}{c}\text { Номер и вид } \\
\text { лицензии }\end{array}$ \\
\hline ООО «Атов-Маг плюс» & 1 & Атовское месторождение & 11333 НЭ \\
\hline \multirow{11}{*}{ ООО «ИНК» } & 2 & Ярактинское месторождение & 02896 НЭ \\
\hline & 3 & Марковское месторождение & 02895 НЭ \\
\hline & 4 & Даниловское месторождение & $02892 \mathrm{HP}$ \\
\hline & 5 & Ангаро-Илимское месторождение & 03024 НЭ \\
\hline & 6 & Нарьягинское месторождение & 03025 НЭ \\
\hline & 7 & Потаповский участок & $02730 \mathrm{HP}$ \\
\hline & 8 & Средненепский участок & $15269 \mathrm{HP}$ \\
\hline & 9 & Ялыкский участок & $15313 \mathrm{HP}$ \\
\hline & 10 & Кийский участок & $15484 \mathrm{HP}$ \\
\hline & 11 & Верхнетирский участок & $03155 \mathrm{HP}$ \\
\hline & 12 & Верхненепский участок & $03156 \mathrm{HP}$ \\
\hline \multirow{2}{*}{ ООО «ИНК-НефтеГазГеология» } & 13 & Аянский участок & $13568 \mathrm{HP}$ \\
\hline & 14 & Аянское месторождение & $13569 \mathrm{HP}$ \\
\hline \multirow{2}{*}{ АО «ИНК-Запад» } & 15 & Западно-Ярактинский участок & $03182 \mathrm{HP}$ \\
\hline & 16 & Большетирский участок & $03183 \mathrm{HP}$ \\
\hline ЗАО «ИНК-Север» & 17 & Северо-Могдинский участок & $14437 \mathrm{HP}$ \\
\hline ООО «Тихоокеанский терминал» & 18 & Аянский (Западный) участок & $02665 \mathrm{HP}$ \\
\hline ОАО «Братскэкогаз» & 19 & Братское месторождение & 01588 НЭ \\
\hline ЗАО «НК «Дулисьма» & 20 & Дулисьминское месторождение & $14578 \mathrm{HP}$ \\
\hline ПАО «Верхнечонскнефртегаз» & 21 & Верхнечонское месторождение & 03185 НЭ \\
\hline \multirow{3}{*}{ ООО «Петромир» } & 22 & Левобережный участок & $10812 \mathrm{HP}$ \\
\hline & 23 & Правобережный участок & $10811 \mathrm{HP}$ \\
\hline & 24 & Ангаро-Ленское месторождение & 14078 НЭ \\
\hline ООО «Иркутбургаз» & 25 & Балаганкинское месторождение & $14263 \mathrm{HP}$ \\
\hline ООО «СибГаз» & 26 & Тутурское месторождение & 15197 НЭ \\
\hline \multirow{4}{*}{ ПАО «Газпром» } & 27 & Ковыктинское месторождение & 15939 НЭ \\
\hline & 28 & Южно-Усть-Кутский участок & $14424 \mathrm{HP}$ \\
\hline & 29 & Чиканское месторождение & 15940 НЭ \\
\hline & 30 & Хандинский участок Ковыктинского ГКМ & $15731 \mathrm{H \ni}$ \\
\hline \multirow{7}{*}{ ПАО «НК «Роснефть» } & 31 & Восточно-Сугдинский участок & $13547 \mathrm{HP}$ \\
\hline & 32 & Санарский участок & $13670 \mathrm{HP}$ \\
\hline & 33 & Могдинский участок & $13671 \mathrm{HP}$ \\
\hline & 34 & Даниловский участок & $13713 \mathrm{HP}$ \\
\hline & 35 & Преображенский участок & $14272 \mathrm{HP}$ \\
\hline & 36 & Умоткинский участок & $14466 \mathrm{HP}$ \\
\hline & 37 & Немчуйский участок & $03213 \mathrm{HP}$ \\
\hline \multirow{2}{*}{ OАО «Сургутнефтегаз» } & 38 & Рассохинский участок & $02347 \mathrm{HP}$ \\
\hline & 39 & Пилюдинский участок & $14402 \mathrm{HP}$ \\
\hline \multirow{2}{*}{ ООО «Авангард» } & 40 & Антоновский участок & $02349 \mathrm{HP}$ \\
\hline & 41 & Средне-Окинский участок & $02348 \mathrm{HP}$ \\
\hline ООО «Када-НефтеГаз» & 42 & Заславский участок & $02372 \mathrm{HP}$ \\
\hline
\end{tabular}


Окончание табл. 1

\begin{tabular}{|c|c|c|c|}
\hline Недропользователь & $\begin{array}{l}\text { № } \\
\Pi / \pi\end{array}$ & $\begin{array}{c}\text { Наименование участка } \\
\text { или месторождения }\end{array}$ & Номер и вид лицензии \\
\hline \multirow{2}{*}{ ООО «Восток-Энерджи» } & 43 & Западно-Чонский участок & $14270 \mathrm{HP}$ \\
\hline & 44 & Верхнеичерский участок & $14271 \mathrm{HP}$ \\
\hline \multirow{2}{*}{ ООО «Газпромнефрть-Ангара»» } & 45 & Вакунайский участок & $02567 \mathrm{HP}$ \\
\hline & 46 & Игнялинский участок & $02568 \mathrm{HP}$ \\
\hline ООО «Антей» & 47 & Южно-Кытымский участок & $14303 \mathrm{HP}$ \\
\hline ООО «ПромГазЭнерго» & 48 & Усть-Илгинский участок & $14509 \mathrm{HP}$ \\
\hline ООО «ВерхоленскГазДобыча» & 49 & Верхоленский участок & $14762 \mathrm{HP}$ \\
\hline ЗАО «ВСТО-НефтеГаз» & 50 & Ербогаченский участок & $14531 \mathrm{HP}$ \\
\hline ООО «НафртаТраст» & 51 & Тунакский участок & $14765 \mathrm{HP}$ \\
\hline ООО «ФинансГео» & 52 & Куйтунский участок & $14383 \mathrm{HP}$ \\
\hline ООО «Георесурс» & 53 & Радуйский участок & $14375 \mathrm{HP}$ \\
\hline ООО «Усть-Кут-НефттеГаз» & 54 & Казаркинский участок & $02521 \mathrm{HP}$ \\
\hline ЗАО «Киренск-НефртеГаз» & 55 & Киренский участок & $14515 \mathrm{HP}$ \\
\hline $\begin{array}{l}\text { ООО «Восточносибирская } \\
\text { Управляющая Компания» }\end{array}$ & 56 & Ромашихинский участок & $15334 \mathrm{H} \Pi$ \\
\hline \multirow{7}{*}{ ЗАО «ПК «ДИТЭКО» } & 57 & Северо-Марковский участок & $02982 \mathrm{HP}$ \\
\hline & 58 & Знаменский участок & $02981 \mathrm{HP}$ \\
\hline & 59 & Усть-Кутский участок & $15448 \mathrm{HP}$ \\
\hline & 60 & Нижнеудинский участок & $15515 \mathrm{HP}$ \\
\hline & 61 & Бельский участок & $02984 \mathrm{HП}$ \\
\hline & 62 & Качугский участок & $03055 \mathrm{HП}$ \\
\hline & 63 & Присаянский участок & 03066 НП \\
\hline ПАО «Иркутскэнерго» & 64 & Купский участок & $15465 \mathrm{HP}$ \\
\hline ООО «Нормаль Ойл» & 65 & Шонский участок & $02985 \mathrm{HП}$ \\
\hline ООО «ТехЭнерго» & 66 & Криволукский участок & $14369 \mathrm{HP}$ \\
\hline ООО «АтлантБурСервис» & 67 & Леоновский участок & 03109 НП \\
\hline ООО «НК-Энерго» & 68 & Кытымский участок & $03204 \mathrm{HP}$ \\
\hline ООО «Техноконсалт» & 69 & Верхнеульканский участок & $03206 \mathrm{HP}$ \\
\hline \multirow{3}{*}{ ООО «ВОССЭТ» } & 70 & Нижнекиренский участок & $03205 \mathrm{HP}$ \\
\hline & 71 & Казаркинский (Восточный) участок & $03207 \mathrm{HP}$ \\
\hline & 72 & Ичерский (Южный) участок & $03208 \mathrm{HP}$ \\
\hline $\begin{array}{l}\text { ООО «Казарки Нефртегаз } \\
\text { Геология» }\end{array}$ & 73 & Северо-Куленгский участок & $03212 \mathrm{HP}$ \\
\hline
\end{tabular}

В Иркутской области, по данным на начало 2017 г., разведкой и добычей месторождений занимаются 38 компаний (см. табл. 1). Наибольшее количество лицензий принадлежит ООО «ИНК» - 11 лицензий ${ }^{3}$, далее - ПАО «НК «Роснефть» и ЗАО «ПК «ДИТЭКО» по 7 лицензий, ПАО «Газпром» - 4 лицензии [8, с. 70$]$.

3 Иркутская нефртяная компания увеличила в 2016 году добычу УВС на 39 \% [Электронный ресурс]. URL: http://www.irkutskoil.ru.
В 2016 г. Роснедра и Иркутскнедра выдали 157 лицензий на пользование недрами на территории Иркутской области (углеводородное сырье, золото, уран, подземные и минеральные воды, уголь, другие твердые полезные ископаемые - известняки, медь, никель, железные и полиметаллические руды и т. д.), в том числе $25-$ на углеводородное сырье. Удельный вес лицензий на углеводородное сырье в общем числе выданных лицензий составляет 15,9 \% (табл. 2). 
Таблица 2

Динамика числа выданных Роснедрами и Иркутскнедрами лицензий на пользование недрами на территории Иркутской области по годам

\begin{tabular}{|c|c|c|c|c|c|c|c|c|c|c|c|c|}
\hline \multirow{2}{*}{ Показатель } & \multicolumn{9}{|c|}{ Год } & \multirow{2}{*}{ Всего } & \multirow{2}{*}{$\begin{array}{c}\text { В среднем } \\
\text { за год }\end{array}$} & \multirow{2}{*}{$\begin{array}{c}2016 \text { г. } \\
\text { к } 2008 \text { г., \% }\end{array}$} \\
\hline & 2008 & 2009 & 2010 & 2011 & 2012 & 2013 & 2014 & 2015 & 2016 & & & \\
\hline Всего выдано лицензий, ед. & 118 & 75 & 92 & 107 & 69 & 144 & 113 & 80 & 157 & 955 & 106 & 133,1 \\
\hline $\begin{array}{l}\text { В том числе на углеводо- } \\
\text { родное сырье }\end{array}$ & 22 & 6 & 4 & 8 & 8 & 13 & 7 & 15 & 25 & 108 & 12 & 113,6 \\
\hline $\begin{array}{l}\text { Удельный вес лицензий } \\
\text { на углеводородное сырье } \\
\text { в общем числе выданных } \\
\text { лицензий, \% }\end{array}$ & 18,6 & 8,0 & 4,3 & 7,5 & 11,6 & 9,0 & 6,2 & 18,8 & 15,9 & 11,3 & 11,3 & - \\
\hline
\end{tabular}

Количество выдаваемых лицензий на пользование недрами ежегодно колеблется от 69 до 157, в том числе на углеводородное сырье - от 4 в 2010 г. до 25 в 2016 г. За 2008-2016 гг. Роснедрами и Иркутскнедрами выдано 955 лицензий на пользование недрами на территории Иркутской области, в том числе на углеводородное сырье - 108 лицензий. В среднем за год производится выдача более 100 лицензий, из которых 12 приходится на углеводородное сырье [9, с. 105].

Все обнаруженные в Иркутской области месторождения находятся в распределенном фонде недр. Запасы углеводородного сырья по всем месторождениям учитываются в Государственном балансе запасов полезных ископаемых. Наиболее крупными являются Верхнечонское нефтегазоконденсатное и Ковыктинское газоконденсатное месторожде- ния ${ }^{4}$, в которых сосредоточено соответственно 59 \% нефти и 85 \% газа от разведанных в Иркутской области запасов углеводородного сырья. В 2016 г. по результатам геологоразведочных работ проведена переоценка запасов Верхнечонского, Дулисьминского, Ярактинского, Даниловского, Западно-Ярактинского нефтегазоконденсатных месторождений, Ичёдинского нефтяного и Ангаро-Илимского газового месторождений.

По данным [10, с. $2 ; 11$, с. 229; 12, с. 13] в табл. 3 представлена динамика объемов добычи нефти, газа и конденсата в Иркутской области за период с 2001 по 2016 г.

4 На Ковыкте успешно проведены испытания опытно-промышленной мембранной установки по выделению гелия и перевыполнены планы по добыче углеводородов [Электронный ресурc]. URL: http:// irkutsk-dobycha.gazprom.ru.

Динамика объемов добычи нефти, газа и конденсата в Иркутской области в 2001-2016 гг.

Таблица 3

\begin{tabular}{|c|c|c|c|}
\hline & Нефтт, тыс. т & Газ, млн м ${ }^{3}$ & Конденсат, тыс. т \\
\hline Год & $\begin{array}{c}\text { ООО «ИНК», ПАО «Верх- } \\
\text { нечонскнефтегаз», } \\
\text { ЗАО «НК «Дулисьма», } \\
\text { ЗАО «ИНК-Север», ПАО «НК } \\
\text { «Роснефть», АО «ИНК-Запад», } \\
\text { ООО «ИНК-НефтеГазГеология», } \\
\text { ООО «Газпромнефть-Ангара» }\end{array}$ & $\begin{array}{c}\text { ПАО «Верхнечонскнефтегаз», } \\
\text { ООО «Атов-Маг Плюс», } \\
\text { ООО «ИНК», ПАО «Газпром», } \\
\text { ОАО «Братскэкогаз», ЗАО «НК } \\
\text { «Дулисьма», } \\
\text { ООО «ИНК-НефтеГазГеология» }\end{array}$ & $\begin{array}{c}\text { ООО «Атов-Маг } \\
\text { Плюс», ООО «ИНК», } \\
\text { ПАО «Газпром», ОАО «Брат- } \\
\text { скэкогаз», ЗАО «НК «Дулись- } \\
\text { ма», ООО «ИНК-НефртГГаз- } \\
\text { Геология» }\end{array}$ \\
\hline 2001 & 42,0 & 28,5 & 5,0 \\
\hline 2002 & 46,0 & 35,0 & 6,0 \\
\hline 2003 & 72,0 & 87,7 & 12,1 \\
\hline 2004 & 149,0 & 79,9 & 15,4 \\
\hline 2005 & 167,4 & 135,8 & 23,5 \\
\hline 2006 & 157,0 & 213,8 & 40,3 \\
\hline 2007 & 218,0 & 228,0 & 43,0 \\
\hline 2008 & 451,0 & 328,0 & 51,0 \\
\hline 2009 & 1592,1 & 397,3 & 49,2 \\
\hline 2010 & 3261,1 & 629,2 & 71,1 \\
\hline 2011 & 6523,4 & 1059,8 & 90,8 \\
\hline
\end{tabular}


Окончание табл. 3

\begin{tabular}{|c|c|c|c|}
\hline & Нефть, тыс. т & Газ, млн м ${ }^{3}$ & Конденсат, тыс. т \\
\hline Год & $\begin{array}{c}\text { ООО «ИНК», ПАО «Верх- } \\
\text { нечонскнефтегаз», } \\
\text { ЗАО «НК «Дулисьма», } \\
\text { ЗАО «ИНК-Север», ПАО «НК } \\
\text { «Роснефть», АО «ИНК-Запад», } \\
\text { ООО «ИНК-НефтеГазГеология», } \\
\text { ООО «Газпромнефть-Ангара» }\end{array}$ & $\begin{array}{c}\text { ПАО «Верхнечонскнефтегаз», } \\
\text { ООО «Атов-Маг Плюс», } \\
\text { ООО «ИНК», ПАО «Газпром», } \\
\text { ОАО «Братскэкогаз», ЗАО «НК } \\
\text { «Дулисьма», } \\
\text { ООО «ИНК-НефтеГазГеология» }\end{array}$ & $\begin{array}{c}\text { ООО «Атов-Маг } \\
\text { Плюс», ООО «ИНК», } \\
\text { ПАО «Газпром», ОАО «Брат- } \\
\text { скэкогаз», ЗАО «НК «Дулись- } \\
\text { ма», ООО «ИНК-НефтеГаз- } \\
\text { Геология» }\end{array}$ \\
\hline 2012 & 9923,0 & 2465,0 & 164,0 \\
\hline 2013 & 11096,0 & 3317,0 & 326,0 \\
\hline 2014 & 13026,0 & 3521,6 & 170,4 \\
\hline 2015 & 15205,0 & 4123,0 & 225,0 \\
\hline 2016 & 17715,0 & 5077,0 & 323,0 \\
\hline $\begin{array}{c}2016 \text { г. } \\
\text { к } 2001 \text { г., } \\
\text { раз }\end{array}$ & 422,0 & 178,0 & 65,0 \\
\hline $\begin{array}{c}2016 \text { г.к } \\
2015 \text { г. } \\
\%\end{array}$ & 116,5 & 123,1 & 143,6 \\
\hline
\end{tabular}

Объемы добычи углеводородного сырья в Иркутской области в 2001-2016 гг. имеют тенденцию к ежегодному увеличению. За 15 лет в Иркутской области произошло увеличение объемов добычи нефти - на 17673 тыс. т (в 422 раза), газа — на 5 048,5 млн м3 (в 178 раз), конденсата — на 318 тыс. т (в 65 раз).

Добыча углеводородного сырья в 2017 г. осуществлялась в основном на Верхнечонском, Ярактинском, Марковском, Даниловском, Дулисьминском, Западно-Аянском, Северо-Даниловском, Игнялинском нефртегазоконденсатных месторождениях; им. Синявского и Ичёдинском нефртяных месторождениях; Ковыктинском, Атов- ском, Братском газоконденсатных месторождения ${ }^{5}$.

Открытие новых месторождений связано с проведением геологоразведочных работ - комплекса специальных геологических мероприятий с целью поиска, обнаружения и подготовки к промышленному освоению месторождений нефти и газа (табл. 4).

${ }^{5}$ Оценка воздействия на окружающую и социальную среду для системы транспорта нефти Даниловского НГКМ / ООО «ИНК». Иркутск, 2011. 270 с. ; Оценка воздействия на окружающую природную и социальную среду при разработке Ярактинского месторождения (нефтяная и газовая части) / ООО «ИНК». Иркутск, 2008. 507 c.

Таблица 4

Объемы геологоразведочных работ, проводившихся в Иркутской области в 2010-2015 гг., в натуральном выражении

\begin{tabular}{|c|c|c|c|c|c|c|c|c|}
\hline \multirow{2}{*}{ Геологоразведочные работы } & \multicolumn{7}{|c|}{ Год } & \multirow{2}{*}{$\begin{array}{c}2016 \text { г. } \\
\text { к } 2010 \text { г. } \\
\%\end{array}$} \\
\hline & 2010 & 2011 & 2012 & 2013 & 2014 & 2015 & 2016 & \\
\hline $\begin{array}{l}\text { Опорное и параметрическое бурение } \\
\text { на нефть и газ, м }\end{array}$ & - & - & 4950 & 1660 & - & - & - & - \\
\hline Поисковое бурение на нефть и газ, м & 29153 & 40594 & 14261 & 33703 & 26454 & 14893 & 29386 & 100,8 \\
\hline Разведочное бурение на нефть и газ, м & 7971 & 13837 & 12501 & 26333 & 57111 & 25489 & 26647 & 334,3 \\
\hline Механическое колонковое бурение, м & 59880 & 97314 & 156365 & 57607 & 83565 & 40382 & 56033 & 93,6 \\
\hline Ударно-механическое бурение, м & 65510 & 70098 & 86300 & 97631 & 59394 & 42307 & 47222 & 72,1 \\
\hline Горные подземные работы, м & - & 2200 & - & 3209 & 90481 & 43989 & 120963 & - \\
\hline Геологическая съемка M 1:200 000, м & - & - & - & 562 & 13267 & 10468 & 4842 & - \\
\hline Сейсморазведка профильная, тыс. м & 11262 & 5472 & 3071 & 5733 & 6417 & 3197 & 3317 & 29,5 \\
\hline Сейсморазведка площадная, км² & - & 1100 & 2015 & 1863 & 2428 & 4094 & 5134 & - \\
\hline
\end{tabular}


Опорное и параметрическое бурение на нефть и газ в 2014-2016 г. не производилось, объемы поискового бурения в 2016 г. по сравнению с 2010 г. не изменились, разведочного бурения на нефть и газ, наоборот, увеличились в 3,3 раза. Объемы механического колонкового бурения, ударно-механического бурения и горных подземных работ в 2016 г. по сравнению с предыдущим годом увеличились и составили 56033 м, 47222 м и 120963 м соответственно. Снижение произошло по объемам геологической съемки М 1:200 000, сейсморазведки профильной, а вот по объемам сейсморазведки площадной, наоборот, наблюдается рост.

В табл. 5 представлен объем финансирования геологоразведочных работ по важнейшим видам полезных ископаемых (нефрть, газ, конденсат и др.) в Иркутской области, Сибирском федеральном округе и России в целом.

В Иркутской области в 2015 г. объем фиинансирования геологоразведочных работ по важнейшим видам полезных ископаемых за счет всех источников составлял 18430 млн р. По сравнению с 2005 г. наблюдается увеличение фринансирования геологоразведочных работ в 10,2 раза, в то время как в Сибирском федеральном округе - в 5,2 раза, по России в целом - в 3,4 раза. Это говорит об интенсивном увеличении объемов геологоразведочных работ именно в Иркутской области.

Одним из важных этапов разработки месторождений является бурение. К глубокому разведочному бурению на нефть и природный газ относится бурение опорных, параметрических, поисковых и разведочных скважин с целью региональных исследований, поиска и разведки нефртяных и газовых месторождений независимо от источников фринансирования.

В табл. 6 представлена динамика объемов глубокого разведочного бурения на нефть и газ в Иркутской области, Сибирском федеральном округе и России.

Таблица 5

Объем финансирования геологоразведочных работ по важнейшим видам полезных ископаемых в 2005-2013 гг., млн р.*

\begin{tabular}{|c|c|c|c|c|c|c|c|c|c|c|}
\hline \multirow{2}{*}{ Регион } & \multicolumn{9}{|c|}{ Год } & \multirow{2}{*}{$\begin{array}{c}2013 \text { г. } \\
\text { к } 2005 \text { г. } \\
\text { раз }\end{array}$} \\
\hline & 2005 & 2006 & 2007 & 2008 & 2009 & 2010 & 2011 & 2012 & 2013 & \\
\hline $\begin{array}{l}\text { Российская Феде- } \\
\text { рация }\end{array}$ & 75461 & 95968 & 138448 & 180855 & 172029 & 199164 & 216332 & 249759 & 258778 & 3,4 \\
\hline $\begin{array}{l}\text { Сибирский фреде- } \\
\text { ральный округ }\end{array}$ & 9995 & 11535 & 17109 & 26212 & 36764 & 53655 & 53905 & 54194 & 51464 & 5,2 \\
\hline Иркутская область & 1803 & 2353 & 3416 & 6531 & 9801 & 13130 & 12938 & 14953 & 18430 & 10,2 \\
\hline
\end{tabular}

* Составлена по данным Росстата. URL: http: / /cbsd.gks.ru.

Таблица 6

Объемы глубокого разведочного бурения на нефть и газ в 2005-2013 гг., тыс. м *

\begin{tabular}{|c|c|c|c|c|c|c|c|c|c|c|}
\hline \multirow{2}{*}{ Регион } & \multicolumn{9}{|c|}{ Год } & \multirow{2}{*}{$\begin{array}{c}2013 \text { г. } \\
\text { к } 2005 \text { г. , } \\
\%\end{array}$} \\
\hline & 2005 & 2006 & 2007 & 2008 & 2009 & 2010 & 2011 & 2012 & 2013 & \\
\hline Российская Федерация & 1079 & 1211 & 1488 & 1432 & 901 & 1169 & 1235 & 1258 & 1222 & 113,2 \\
\hline Сибирский федеральный округ & 78 & 97 & 168 & 165 & 144 & 237 & 209 & 132 & 148 & 190,9 \\
\hline Иркутская область & 8 & 20 & 50 & 19 & 18 & 37 & 52 & 36 & 69 & 905,3 \\
\hline
\end{tabular}

* Составлена по данным Росстата. URL: http://cbsd.gks.ru.

В 2005-2013 гг. в Иркутской области произошло увеличение объемов глубокого разведочного бурения на нефть и газ в 9,1 раза, в Сибирском федеральном округе - в 1,9 раза, в Российской Федерации в целом только на 13,2\%. Стоит отметить, что кроме глубокого разведочного бурения на нефть и газ в Иркутской области проводилось эксплуатационное бурение.

Таким образом, на основании изложенного можно сформулировать следующие выводы:

1. Иркутская область является одним из перспективных регионов России по добыче углеводородного сырья (нефть, газ и конденсат).

2. По состоянию на начало 2017 г. в Иркутской области открыто 38 месторождений углеводородного сырья. Объемы добычи нефти, газа и конденсата в Иркутской области имеют тенденцию к ежегодному увеличению, разрабатываются новые месторождения.

3. Объемы геологоразведочных работ ежегодно растут, в связи с чем имеются хорошие предпосылки для открытия новых месторождений нефти, газа и конденсата. 


\section{СПИСОК ИСПОЛЬЗОВАННОЙ ЛИТЕРАТУРЫ}

1. Винокуров М. А. Перспективы газификации Иркутской области / М. А. Винокуров // Известия Иркутской государственной экономической академии. - 2009. - № 3 (65). - С. 30-33.

2. Винокуров М. А. Экономика Иркутской области : в 6 т. / М. А. Винокуров, А. П. Суходолов. -Иркутск : Облмашинформ, 1999. - Т. 2. - 310 с.

3. Суходолов А. П. Нефть и природный газ Иркутской области / А. П. Суходолов, В. А. Назарьев, В. Л. Неустроев / / Наука в Сибири. - 1998. - 9 янв. - С. 5.

4. Каламкаров Л. В. Нефтегазоносные провинции и области России и сопредельных стран / Л. В. Каламкаров. - М. : Нефть и газ, 2005. - 571 с.

5. Состояние и проблемы воспроизводства минерально-сырьевой базы углеводородов в Восточной Сибири и Республике Саха (Якутия) / А. Э. Конторович, Л.В.Эдер, И.В.Филимонова, С. А. Моисеев // Минеральные ресурсы России. Экономика и управление. - 2014. - № 6. - С. 15-27.

6. Винокуров М. А. Ресурсы и запасы природного газа в Иркутской области / М. А. Винокуров / / Известия Иркутской государственной экономической академии. - 2009. - № 2 (64). - С. 24-30.

7. Боровиков И. С. Состояние фонда месторождений нефти и газа территорий Дальневосточного региона [Электронный ресурс] / И. С. Боровиков / / Нефтегазовая геология. Теория и практика. - 2008. - Т. 3, № 4. Режим доступа: http://www.ngtp.ru/rub/4/55_2008.pdf.

8. Минерально-сырьевой потенциал Иркутской области / В. А. Назарьев, А. В. Царев, Н. А. Суслов, В. И. Васильев / / Геология и минерально-сырьевые ресурсы Сибири. - 2010. - № 1. - С. 69-75.

9. Современное состояние недропользования на нефть и газ территории Сибирской платформы в связи с реализацией мероприятий государственной «Программы геологического изучения и предоставления в пользование месторождений углеводородного сырья Восточной Сибири и Республики Саха (Якутия)» / К. В. Старосельцев, В. Г. Акимов, И. И. Черепанова, В. А. Эрнст / / Геология и минерально-сырьевые ресурсы Сибири. - 2012. - № 2. - С. 104-109.

10. ЖарковаЕ. В. Нефтегазодобывающийкомплекс Иркутской области: развитие ипроблемы [Электронный ресурс] / Е. В. Жаркова / / Нефтегазовая геология. Теория и практика. - 2016. - Т. 11, № 2. - Режим доступа: http: / / www.ngtp.ru/rub/4/22_2016.pdf. — DOI: 10.17353/2070-5379/22_2016.

11. Минерально-сырьевой сектор Азиатской России: как обеспечить социально-экономическую отдачу? / под ред. В. В. Кулешова. - Новосибирск : Изд-во ИЭОПП СО РАН, 2015. - 351 с.

12. Назарьев В. А. Состояние, перспективы воспроизводства и освоения сырьевой базы природного газа Иркутской области / В. А. Назарьев, А. В. Царев / / Минеральные ресурсы России. Экономика и управление. 2009. - № 6. - C. 10-13.

\section{REFERENCES}

1. Vinokurov M. A. Prospects for Gasification of Irkutsk Region. Izvestiya Irkutskoi gosudarstvennoi ekonomicheskoi akademii = Izvestiya of Irkutsk State Economics Academy, 2009, no. 3 (65), pp. 30-33. (In Russian).

2. Vinokurov M. A., Sukhodolov A. P. Ekonomika Irkutskoi oblasti [Economy of Irkutsk Region]. Irkutsk, Oblmashinform Publ., 1999. Vol. 2. 310 p.

3. Sukhodolov A. P., Nazar'ev V. A., Neustroev V. L. Oil and Natural Gas of Irkutsk Oblast. Nauka v Sibiri $=$ Science in Siberia, 1998, 9 January, p. 5. (In Russian).

4. Kalamkarov L. V. Neftegazonosnye provintsii i oblasti Rossii i sopredel'nykh stran [Oil-and-gas Bearing Provinces and Regions of Russia and Neighbouring Countries]. Moscow, Neft' i gaz Publ., 2005. 571 p.

5. Kontorovich A. E., Eder L. V., Filimonova I. V., Moiseyev S. A. The Current State and Challenges of the Replacement of the Mineral Resource Base of Hydrocarbons in Eastern Siberia and the Republic of Sakha (Yakutia). Mineral'nye resursy Rossii. Ekonomika i upravlenie = Mineral Recourses of Russia. Economics and Management, 2014, no. 6, pp. 15-27. (In Russian).

6. Vinokurov M. A. Resources and Reserves of Natural Gas in Irkutsk Region. Izvestiya Irkutskoi gosudarstvennoi ekonomicheskoi akademii = Izvestiya of Irkutsk State Economics Academy, 2009, no. 2 (64), pp. 24-30. (In Russian).

7. Borovikov I. S. Funds of Oil and Gas Fields on the Territory of the Far Eastern Region. Neftegazovaya geologiya. Teoriya i praktika = Petroleum Geology - Theoretical and Applied Studies, 2008, vol. 3, no. 4. Available at: http: / / www.ngtp.ru/rub/4/55_2008.pdf. (In Russian).

8. Nazaryev V. A., Tsarev A. V., Suslov N. A., Vasilyev V. I. Mineral Resource Potential of the Irkutsk Region. Geologiya i mineral' no-syr' evye resursy Sibiri = Geology and mineral resources of Siberia, 2010, no. 1, pp. 69-75. (In Russian)

9. Staroseltsev K. V., Akimov V. G., Cherepanova I. I., Ernst V. A. Current State of Subsoil Use for Oil and Gas Within the Siberian Platform in Connection with Realization of the State «Program of Geological Study and Licening Deposits of Hydrocarbon Raw Materials of Eastern Siberia and the Republic of Sakha (Yakutia)". Geologiya i mineral'no-syr' evye resursy Sibiri $=$ Geology and mineral resources of Siberia, 2012, no. 2, pp. 104-109. (In Russian).

10. Zharkova E. V. The Oil and Gas Producing Complex of Irkutsk Region: Development and Issues. Neftegazovaya geologiya. Teoriya i praktika = Petroleum Geology - Theoretical and Applied Studies, 2016, vol. 11, no. 2. Available at: http://www.ngtp.ru/rub/4/22_2016.pdf. DOI: 10.17353/2070-5379/22_2016. (In Russian).

11. Kuleshov V. V. (ed.). Mineral'no-syr' evoi sektor Aziatskoi Rossii: kak obespechit' sotsial'no-ekonomicheskuyu otdachu? [Natural Resources Sector of Asian Part of Russia: How to Ensure Socioeconomic Return?]. Novosibirsk, the Institute of Economics and Industrial Engineering, Siberian Branch of the Russian Academy of Sciences Publ., 2015. 351 p.

12. Nazaryev V. A., Tsaryov A. V. The State, Replacement and Development Potentialities of the Natural Gas Resource Base in Irkutsk Oblast. Mineral'nye resursy Rossii. Ekonomika i upravlenie = Mineral Recourses of Russia. Economics and Management, 2009, no. 6, pp. 10-13. (In Russian). 


\section{Информация об авторах}

Новиков Александр Викторович - кандидат экономических наук, магистрант, кафедра экономики и управления бизнесом, Байкальский государственный университет, 664003, г. Иркутск, ул. Ленина, 11, e-mail: novirk@ya.ru.

Богомолова Евгения Юрьевна - кандидат экономических наук, доцент, кафедра экономики и управления бизнесом, Байкальский государственный университет, 664003, г. Иркутск, ул. Ленина, 11, e-mail: bogomolova-e-u@mail.ru.

Кородюк Игорь Степанович - доктор экономических наук, профессор, заведующий кафедрой экономики и управления бизнесом, Байкальский государственный университет, 664003, г. Иркутск, ул. Ленина, 11, e-mail: KorodukIS@bgu.ru.

\section{Для цитирования}

Новиков А. В. Характеристика месторождений нефти, газа и конденсата в Иркутской области / А. В. Новиков, Е. Ю. Богомолова, И. С. Кородюк // Известия Байкальского государственного университета. - 2017. - T. 27, № 4. - C. 459-467. - DOI: 10.17150/2500-2759.2017.27.(4).459-467.

\section{Authors}

Alexander V. Novikov - PhD in Economics, Master's Degree student, Department of Economics and Business Management, Baikal State University, 11 Lenin St., 664003, Irkutsk, Russian Federation, e-mail: novirk@ya.ru.

Evgeniya Yu. Bogomolova - PhD in Economics, Associate Professor, Department of Economics and Business Management, Baikal State University, 11 Lenin St., 664003, Irkutsk, Russian Federation, e-mail: bogomolova-e-u@mail.ru.

Igor S. Korodyuk - DSc in Economics, Professor, Head of the Department of Economics and Business Management, Baikal State University, 11 Lenin St., 664003, Irkutsk, Russian Federation, e-mail: KorodukIS@ bgu.ru.

\section{For citation}

Novikov A. V., Bogomolova E. Yu., Korodyuk I. S. Characteristics of Oil, Gas and Gas Condensate Fields of Irkutsk Oblast. Izvestiya Baykal'skogo gosudarstvennogo universiteta $=$ Bulletin of Baikal State University, 2017, vol. 27, no. 4, pp. 459-467. DOI: 10.17150/2500-2759.2017.27.(4).459-467. (In Russian). 